\title{
Dietmar Mieth
}

\section{Self-transcendence in Meister Eckhart}

\section{Meister Eckhart's vernacular project in the service of religious self-awareness}

The importance Meister Eckhart the Lehrmeister and Lebemeister, thus the Parisian magister and vernacular preacher, ascribes to 'equality' is striking. He means both human and religious equality. (cf. Sermon $65, M W$ ) Eckhart addresses all individuals - without distinction of sex - on the basis of equal possibilities. In scholastic philosophy as for Eckhart, of course, 'equality' is a metaphysical, not a sociological category. Inequality of social rank has no influence on this fundamental category, as, 'before God', all are equal, in terms of God's Creation and of their humanity and their salvation. To clarify, we may say that, while plants and animals are unequal, all are 'equal' as God's creatures. When this perspective dominates, a social component arises, as becomes clear in Eckhart's use of the word Eigenschaft, meaning for him subjection to external purposes and ascendancies. In humorous vein against Thomas Aquinas, Eckhart makes the point that Thomas was interested in the inequalities of blades of grass, thus in grasses individually, but that he himself is interested in their equality, thus grass in genere (cf. Sermon 53, $M W$ 281, Pr. 22, $D W$ I, 384-6).

Eckhart addresses individual people as 'souls', and so mostly without regard for differences. He does not, of course, overlook or pass over the differences between individuals, but sees such differences as being leibgebunden, 'tied to the body'. He is also able explicitly to expand on the idea, not least when he indicates that 'my body is more in my soul than my soul is in my body' (Semon 66 and Sermon 21, MW); he goes further when he attests to the perfection of embodied humans as being the 'best', while that of angels is only the highest (cf. Sermon 70, MW 359; Pr. 67, DW III, $c f$. Mieth, $L E$ IV, 95-122).We read in Eckhart's explicit preaching program:

\footnotetext{
When I preach it is my wont to speak about detachment (Abegescheidenheit), and of how man should rid himself of self and all things. Secondly, that man should be in-formed back into the simple good which is God. Thirdly, that we should remember the great nobility (Adel) God has put into the soul, so that man may come miraculously to God. Fourthly, of the purity of the divine nature, for the splendour of God's nature is unspeakable.
}

(Beginning of Sermon 22, MW 152, Pr. 53, EW I, 564, 6-14)

The program is about God's and the soul's Lauterkeit (transparency, clarity). In his concern to formulate scholastic thinking as sermons in the vernacular, Eckhart 
imparts thoughts that, while highly speculative, are expressed by him in terms of a linguistic pool that, created in the context of a spiritual relationship with God, has already itself become vernacular. Speculation in a language that has yet to be employed in speculation often has an innovative result. For this reason, even 19th-century Old-Germanists were first struck by Eckhart's supreme linguistic astuteness as a vernacular preacher. Eckhart is not actively concerned with religious 'experience', in the sense of Bonaventure's cognitio Dei quasi experimentalis, or the same scholar's Three ways to God (De triplici via), thus experience already established and current in the vernacular, in the sense of what in today's parlance is referred to on the basis of historical testimony as mystagogy. But the rich imagery he employs is often interpreted as 'mystic'.

Eckhart is not interested in immersive mysticism, initiation into secret ciphers, or promotion of an ecstatic condition. But he is conscious of telling the absolute truth, come 'direct from the heart of God'. And he insists that, in a sermon, a communicative resonance is possible between preacher and audience and vice-versa. Above all, though, Eckhart's desire is to teach how one may live. Life is not to be shorn of its 'now-ness' on the strength of the future, or of a plan. For God is present in every 'now' more than he is in the flow of time: 'He works, and I come into being' (Sermon 65, $M W$ ). Unity in works, exercise of the heart, individual identity in religious and moral terms: these are his educational project, from which even 'coarse and unschooled' people are expressly not excluded ( $c f$. Divine Comfort, $M W$ 553f., $B g T, E W$ II, 213). It is with such optimism that, here like Socrates, according to the official accusation he 'confused' people.

\section{The early project: self-transcendence in Eckhart's teaching in Erfurt}

Eckhart begins, as a prior in Erfurt (from 1294), by apparently following normal tradition with his Collationes, a title inspired by John Cassian; Eckhart, though, has a new spiritual program in mind, at whose center stands, not 'experience', but, in the tradition of the philosophical maxim 'know thyself', the investigation of one's own sensibility: nim dîn selbes wâr (Talks, MW 489, EW II, 340, 25f.).

There is seldom explicit mention of 'experience' in Eckhart's sermons. And yet he is nolens volens confronted by the question of experience when he speaks spiritually to the 'people'. In Erfurt itself we have accounts of the desire of pious women to achieve an ecstatic state (jubilus) arising from a particular path of 
piety. ${ }^{1}$ From the beginning, however, Eckhart dismisses all guarantees of a particular path to God, emphasizing instead the Weiselosigkeit des Gottfindens, the pathless way to find God; that is to say, it is not the already ritualized path itself that matters, but the way that path satisfies the criteria that Eckhart deploys. ${ }^{2}$

Eckhart orchestrates transcendence of self as a process by which God and humans relate together. Selbst/self is a central concept in medieval spiritual writing. Eckhart's early Erfurt teachings (1294-1298) are commonly cited: nim dîn selbes war und wo dû dich vindest, dâ lâz dich. Observe yourself, and wherever you find yourself, leave yourself: that is the very best way. (cf. lc) He provides a kind of guide to diagnosing one's own sensibility: where you discover yourself, there you must leave yourself. This most widely known and followed of Eckhart's works can be summarized as follows:

Instead of changing themselves internally, pious people want to change themselves externally. For example, they want to imitate others, go on journeys, or enter a monastery. They are not at peace with themselves. They think they have to change the circumstances of their lives, and, in the process, neglect to change themselves internally. For they relate to (external) circumstances in a perverse way. Instead, they ought to learn to change themselves; otherwise they are not at peace, wherever they go, whether into another circle of acquaintance, to another place, or far away. They run far away from themselves, and become lost. Stay with yourself, but leave yourself. However, you forsake external goods, that of itself will not have an effect on you. But, if you step away from your covetous desires, then you can have goods and reputation, but they will no longer matter to you. You must not care for yourself as if you were an all-important possession. You must not even cultivate the longing for your own covetous desires. What Jesus praises in spiritual poverty (Matthew 5:3) is inner freedom from one's own striving to possess and one's own longing. So: 'Pay heed to yourself, and where you then find yourself to be (dich vindest), there leave yourself. That is the best you can do'. So: study your Befindlichkeit. (Be)vinden translates the Latin experiri, the religious experience that is summarized in the technical expression experientia Dei quasi experimentalis (Bonaventure). ${ }^{3}$ Eckharts' 'Talks of Instruction', which I will resume in the following, insists:

What impedes you is that you are always yourself and nothing else. It is your self-will, even if you do not know it and refuse to believe it. For the disquiet that plagues you always comes from your own will, whether you are aware of it or not. (cf. Talks, $M W$ 487ff.) When we think

1 Mundschenk 1997, n. 1610 ff., 243.

2 Cf. on Eckhart's pathless way to God in Mieth 1969.

3 Cf. Geybels 2007. 
a human being should avoid something or seek something in particular, we are usually thinking of places, or people, or a way of life, or stress, or an activity: but this is not to blame for the fact that he is prevented by his way of life or whatever else: you, everywhere, yourself, are what impedes you, for in all these matters you behave wrongly [...].

The 'leaving' meant here is a process of letting go - in the sense of freeing from ties - without end. Whoever lets himself go immediately readmits himself. This leads to a conception of Gelassenheit ('detachment'), today best understood as unreserved surrender. So the bond with God always does as well by the 'leaving' as the 'leaving' itself goes well. God fills a person to the extent that the person is empty. Eckhart constantly poses his listeners the question: where are you, how is it with you? If all is well with you, that is your doing too. The way you are is the way you act.

[...] So begin with yourself, and let yourself be [...]. The more people venture forth, the less they find peace. They act like someone who cannot find the way; the further he goes, the more he becomes lost. So what is he to do? He should first relinquish his own self: then he has relinquished everything. It is true: if a person relinquishes a kingdom or the entire world, but retains his own self, he has given up nothing. Yes! If he has relinquished his own self, whatever he then retains wealth, respect, or whatever: (yet) he has relinquished everything [...].

For, whatever you do not wish to covet, for God's sake you have given that all up and surrendered it. This is why our Lord said: Blessed be the poor in spirit (cf. Matthew 5:3), which is to say those who are poor by their own will. And no-one should doubt this. If there were a better way, our Lord would have said it when he spoke of this: Whoever wishes to follow me, he must first deny himself (Matthew 16:24) - this is the nub of it. Get to know yourself, and, wherever you find yourself, leave yourself there. This is the best way.'

These criteria of 'leaving' deconstruct certain ideals of particularity in the fields of humility, ${ }^{4}$ prayer, penance, poverty, and contemplative immersion, among many others. But it is possible further to construe Eckhart's practical spiritual intention in terms of the fundamental concept Gelassenheit. ${ }^{5}$ In common with the German words Wirklichkeit and Bildung, Gelassenheit cannot be translated into English without shift or loss of meaning. Neither 'calmness' nor 'coolness' fits, and neither does 'composure'; just as 'reality' does not fit for Wirklichkeit, or 'education' for Bildung. This relates to the fact that our fundamental concept Gelassenheit stems from so-called Late-Medieval Dominican mysticism, as represented by Meister Eckhart (ca.1260-1328), Henry Suso (1294-1361), and Johannes Tauler (1300-1361). Conversely, historical linguistic developments and the globalization

4 Cf. Schöller 2009; Witte 2013, 302-30.

5 Cf. Mieth 2014b. 
of English have had such an inverse effect on German usage that Wirklichkeit is now associated with reality, Bildung with instruction or training, and Gelassenheit with calmness or coolness. This represents a loss in central meaning and human meaningfulness. For, if we consider the religious origin of these words in German, Wirklichkeit has something to do with Gottes Wirken, for God is lauteres Wirken (Latin actus purus): it is not a matter of presence, but of dynamic. Similarly, Bildung has something to do with Herzensbildung, and Gelassenheit is not quiescence, but the fundamental stance of self-distancing and surrender. If we look for an element of Eckhart's central message in English, then we find it rendered by 'detachment'. ${ }^{6}$ The sense cannot be expressed in such an integrative form in German. However, rendering it by Eckhart's Abgeschiedenheit or Ledigkeit, 'detachment' brings us closer to our Dominican than, for example, 'calmness'.

\section{3 'Inwardness' - God is internal to humans, not outside or above us. Self-transcendence from the inside out}

When you are inwardly in the right place, then it does not matter where you choose to be. If you are in the wrong place inwardly, then nowhere will be right for you. If you are in the right place, then God is with you, on the street, among human beings. Nothing stands in your way anymore. God shines in everything you come across. God works through you when you are in that place. Then, although circumstances might be changing around you, you are, as it were, constantly 'God-feeling'. This fundamental feeling penetrates you, even when you are at the same time moved by many things. God is active and seeks you out. Nothing stands in his way. You may be helped in this by being in a church, but what matters is a presence of God in every situation. Instead of frantically seeking, you must let yourself be found. The feeling may be compared to a constant thirst: as long as it is unquenched it remains present, whatever else may happen. The thirst dominates your self-awareness (cf. Talk, $M W$, 491ff., $D W$ V, 206). The thirst is slaked by a Durchbruch or 'breakthrough' into an inner source, and the consequence is a life-change, not an external alteration.

One can practise this. Learning to write also begins clumsily until such time as it flows easily from the hand. Learning an instrument, one arrives at facility

6 Cf. Vinzent 2011. 
through practice. So it is with the sense of God: first you have to make an effort, for example in prayer; then it comes of itself.

When we are in this fundamental state of feeling, we can use the possibilities we meet with in the world. Whoever has inner understanding also works well. For God is 'in all things', and to be found in all circumstances. For he is 'pure reality' (Wirklichkeit); he consists entirely in works. Whoever possesses him inwardly, he helps from the inside out. Whoever comes so far, in the midst of works has the sense of being unconstrained and with God.

Anyone might fall into difficulties in this process, or be misled into error. But we can so attune ourselves as to nevertheless remain inwardly in that fundamental state, or be capable of returning to it. Everyone can be weak, but, in finding our way back to our self and to our fundamental state, we draw new strength from our weaknesses. The problem is not the weakness; the problem is wanting what makes us weak and error-prone: that is, renouncing our fundamental state in favour of another state. The problem is not the tendency to sin - we should not wish it away - but the way we react to the tendency.

Remember: it is not that familiar splendour that constitutes love in its fullness, but the intensity of our will. Will is more than splendid feelings ( $c f$. Sermon $65, M W)$. Will must be strong for its own sake, even without the support of pleasant feelings. We can test the strength of the state we are in by opening ourselves up to everyday necessity, and being ready to help the poor and tend the sick, instead of wallowing in pious feelings.

Whoever lets something go, receives back a hundred times as much (cf. Mark 10:29f.). Whoever gives something up receives it as a gift. For whatever such a person then lacks creates space for the unfolding of God's love. Paul even goes so far as to risk being separated from the comfort of Christ's love when what is at stake is his active love for his brothers and sisters (cf. Romans 9:3). Here too, the message is, if you lose comfort you gain greater comfort.

This being so, Eckhart also gives answers to the need for experience, although in a metaphoric of life rather than an instruction to seek experience in a narrow sense. In, for example, the Dionysian Sermon 71 (EW II, 64ff., Sermon 19, $M W$ ) and in the cycle on God's birth in the soul, ${ }^{7}$ he gives such answers to the repeated question: How can we feel something ('bevinden') of this?

7 Cf. $D W$ IV, 1, Sermons 101-4 (102=83 MW, 103=90 MW); on the authenticity of this God's-birth cycle, $c f$. Steer (ed.), ibid. $320 \mathrm{f}$. 


\section{Working from the inside to the outside, in order to mitwirken with God's Wirklichkeit (activitas)}

This brings me to a brief consideration of Eckhart's association with 'mysticism'. Nowhere does Meister Eckhart associate the term with himself. 'Mysticism', understood as the religious experience of profound realities, is a recent concept. ${ }^{8}$ While Eckhart speaks of contemplation and ecstasy, in the sense of particular gifts of grace, he always mentions the act of experience in a distanced sense. Experience assumes that one contemplates one's contemplation, thus observing oneself as it were in unity with God, watching oneself 'in the act'. ${ }^{9}$ It is more important to Eckhart that one should 'know' of that unity, even without any accompanying experiential act. 'Knowing', Wissen, is here meant in the sense of wisdom and accomplishment. What is central is Isticheit, the ineluctable knowledge that something 'is', not that it can be typified in distinct categories. ${ }^{10}$ The allocation is ontological, not epistemological or psychological. Implied here is an end to the practice of admiring people on account of their explicit, ecstatic Jubilus, or their particular attributes ${ }^{11}$ : a habit that can lead to error. Only practical change that a person has brought about in his or her own life, in the sense of works of love, is reliable:

\footnotetext{
You often ask how you ought to live. Now pay close attention. Just as I have told you about the image - that is the way you should live! You should be His and for Him, you should not be your own or for yourself, or belong to anyone.... I declare truly that, as long as anything is reflected in your mind, which is not the eternal Word, or which looks away from the eternal Word, then, good as it may be, it is not the right thing. For he alone is a good man who, having set at naught all created things, stands facing straight, with no side-glances, towards the eternal Word, and is imaged and reflected there in righteousness. That man draws from the same source as the Son, and is himself the Son.
}

(Sermon 14, $M W$ 116ff., Pr.16b, EW I, 192)

'God has not bound man's salvation to any special mode'. You following Eckhart, must rather draw all good ways into your own way (Talks, $M W 505$; $D M B R, D W \mathrm{~V}, 251,10-4)$. It is thus a question of self and experience, but also of a successful path to a good life.

But: if God withdraws and conceals himself, what can I do?

8 Cf. de Certeau, 2010, 31.

9 Cf. Vinzent 2014, 220.

$10 C f$. my interpretation of Sermon $D W 67$ (MW 70), LE IV, $102 \mathrm{ff}$. Cf. besides Beccarisi 2005.

11 For 'jubilus': $c f$. the description of the Béguines in Nicolaus von Bibra in Mundschenk 1997, n.1. 
Distinguish what you feel and what comforts you from everything else. For, even towards suffering, you can behave as if you were being comforted. God suffers with you. His readiness to experience pain and his ability to do so are greater than ours. Whatever pain hits us hits him harder, because he is even more sensitive to it. Does not his suffering make our bitterness sweet? The light shines in the darkness: we do not see it in the daylight.

You can behave towards God in such a way that you let him be, and do not keep him for yourself. Then you can abandon yourself, as Paul abandoned himself to the will of God ( $c f$. Acts 9:6), as Mary committed her will to the will of God. As we have seen, Eckhart repeats often: You become truly human by ceasing to want for yourself. It is a question of not blocking the way with self-will when God's will wishes to pass through you. There are many people in heaven who did not quite manage that (you can cross the sea even on a light breeze). But that is the direction to take to the main prize: to be enveloped in God, wearing him 'like a cap on your head' (Talks, $D W \mathrm{~V}, 228,4$; tr. DMBR). God allows himself to be borne on our tongue, so that we may remark what is really sweet and delicious.

\section{How can we become certain of eternal life? (cf. Talks, MW 502, DW V, 240-4)}

There is a certainty through inner epiphany, which is given to few people and can be subject to self-deception. But there is also the certainty of love, and this is greater, more 'authentic', more credible, and more certain. It relies on daily contact with love. All creatures and human friendships are involved in this contact. Whoever loves is not afraid ( $c f .1$ John 4:18). Whoever loves is wrapped in the cloak of forgiveness ( $c f .1$ Peter 4:8). Love erases everything and begins anew. The more it erases, the more it is increased ( $c f$. Luke 7:47).

God comes near to you, however far away you may feel. (cf. lc. 249-51, 5) God stands before your door: leave it open for him! And do not be severe with yourself if you cannot take the path that everyone reveres. For there are many paths ( $c f .1$ Corinthians 7:24). One path to the good is not to be pitted against another. You should not despise the ways taken by others. You yourself must not be fickle in the ways and paths that you take. You may learn from role models, but do not copy them! This even applies to Jesus Christ: we do not have to fast for 40 days as we are told he did. Let everyone choose their own way, following Christ and not trying to copy him. Fasting in Jesus' sense is also not to utter a word when silence is preferable: or not to respond to an insult.

If you are inwardly secure in your direction, then fine clothes are not a consideration: they do not elevate you, but neither do they damage you (cf. Talks, MW 
506ff.; EW II, 388ff.). It is the same with good food with your family or in other company. Be happy and give thanks for it. There is a time for fasting, and a time for eating. Joy and sorrow have their time. We can even learn from Jesus Christ himself that blessings can lie in sorrow. You must, therefore, not shine in these things, in eating and dressing, by the regard you wish to create. It is not forbidden to cook or put on something special: such a stricture too could be burdensome. But you must not be overweening on your own account; much rather be 'overweening' on Christ's account. If your works come out of him, he will take them up.

\section{To be careless in the midst of your works (cf. Talks, MW 492ff.; DWV, 209-11)}

How do we practice finding and embracing God in all things? We must remove from our works the impediment of our inner direction. If we succeed in that, we can work and delight in our works, without mirroring ourselves in the outcome. For then we embrace our works as a gift from God, that is to say as a continuation of his works and his authorship. It is a question of disengaging inwardly, and of the state of being disengaged (Abgeschiedenheit). This is our preparation for correctly receiving the gifts of God: to learn that it is not a question of magnifying something to hang on the wall for our own glory. God wishes to find himself again in our will. The correct ethic does not seek success in the sense of a goal; it allows in what God wants for the world. This can be a strong and good feeling, but that feeling can also deceive if it does not identify itself as inner surrender.

\section{Inner and outer works (cf. Talks, MW 512; EW II, 404,14-406,3)}

We may not remain inactive in our inwardness. Works are important, as long as they are works performed with God. For inwardness must break out in works, and works lead back into inwardness: works outward and inward together. But it is a question of 'working from the inside outwards'. We can also work on inwardness, for example through humility (see above). The highest point of exaltation lies in the lowest point of self-abasement. The smallest is the greatest ( $c f$. Mark 9:35). They who can give receive most. We owe to God the honour of giving. All that we have in the form of gifts is only 'lent' to us. We must therefore dispossess ourselves inwardly. For God himself alone wishes to be our entire possession. That is true poverty: to be empty and at the same time newly replenished. Eckhart asserts with Paul: 'We must have as if we had not', and yet possess all things (2 Corinthians 6:10). 
God does not give me the best that I can in any way imagine for myself; and even this is as I must want it. He gives when we take back our own expectations. Whether God works with nature in humans, as the creator, or with grace as the savior, is hard to distinguish here. Eckhart has it that the particular course the water takes to flow into a garden is not as important as that the garden gets watered (cf. Talks, MW 521, EW II, 430,29 - 432,4).

Eckhart as a Dominican belongs to the poverty faction. But he does not teach emulation of Jesus' poverty, as Francis does, but emulation of God's wealth. God is rich because he lacks nothing; but he keeps hold of none of his wealth for himself. Eckhart - without disavowing outward poverty - thus espouses an inner concept of poverty: not to have, not to know, not to want; but to relinquish all this to God's works.

\section{Transcending self in God's birth}

God's incarnation is for Eckhart the central perspective in Christian theology, and, for him, the historical event of Christ's birth represents only an occasion for more precise reflection on that central theme. ${ }^{12}$ The significance of this for Eckhart is: as well as a creatio continua ('perpetual Creation') there is an incarnatio continua ('perpetual Incarnation'); which is to say, an event that has both always been consummate, and at the same time is in the process of being consummated at every moment as a work of God. From this perspective, Eckhart not only sees the world and humanity differently, but also the Trinity, so to speak retroactively, at its origin or in principle. Insofar as (according to Boethius) a human being not, say, an angel - is a 'person' in the sense of individual substance, Christ is a 'person' through his humanity. But it is not only on Earth that he has this quality, but also in the Trinity. In this way, through the perpetual act of God's incarnation, relationships (relationes) in the Trinity become relationships between persons. ${ }^{13}$ The process not only changes our understanding of the Trinity, but also 'ennobles' the nature of humanity. There is thus a kind of return-birth, in which humanity, in actively collaborating in God's Wirklichkeit, reinforces the dynamic of the relationship between body, soul, and the divine (the Trinity). ${ }^{14}$

What happens during the process of being borne and being born? Many think only of the 'product', the child. But the father becomes a father only when he has

12 Cf. Mieth 2012 on the following.

13 Cf. Pr. 67, DW III, Sermon 70 MW. Cf. Mieth, LE IV.

14 Cf. Mieth 2014a, 63-72. 
a son or a daughter, the mother a mother only when she has a son or a daughter. Eckhart expands this rationale to the extent of saying, 'God becomes when all creatures pronounce God' (Sermon 109, DW IV, 771, 5ff.). The word 'God' comes into being by there being people who can utter it, even though they do not reach the obscure depths of the deity by doing so. God is also present within belief after coming into being, but then he is above all names.

Birth as a divine self-revelation is to be understood as an event in time that reveals to us a constant, intense gesture of devotion by God. At the same time, again according to Eckhart, it is to be understood as a becoming without time, that is to say a constant, perennial motion ( $c f$. In John n. 8, $L W$ III, 8 f.). This motion is part of God's plan of creation, which we are not to understand as if he lives before and above us: by this extreme level of devotion, he lives in us. John's gospel begins: 'In the beginning was the word', and Eckhart equates this with the beginning of creation. 'In the beginning', he says, 'is not the same as "at" the beginning'. Eckhart knows that creation must happen constantly: God is not a clock-maker, who winds the mechanism at the beginning and then constantly intervenes to put it right.

Eckhart understands the Word (in the sense of John 1:1) as a speech event: something issues from and at the same time remains in the speaker. That is very easy for us to comprehend and validate. The same applies to the eyes' outward gaze: it simultaneously depicts in us the image of what is seen. Or he speaks of an echo, in which the sound is and at the same time rebounds; or of warmth left behind in the night by a sunny day: a vestige of the light.

God becoming human is for Eckhart at the same time a revelation of the general process of becoming human: God meant much more by his irreversible association with humanity than merely to live with humans on Earth. Humanity and divinity are inextricably interwoven, not merely since the time of Jesus, but in the sense of revelation working and affecting the past and the future, fulfilling itself in time, and at the same time located transversely to time.

Language mediates between this emblematic birth, across time and yet in time, and humanity's creative, self-knowing profession of self, finding expression in a reciprocal birthing process not to be confused with rebirth. For humanity, in its own works that themselves emerge from God's Wirklichkeit, also gives birth to God. The only way we have the 'Word' is in words, but these refer to a perspective on Wirklichkeit where this Wirklichkeit is not 'given', but is in the process of arising. However, this potential to emerge is God's Creation, whether as the becoming of the world or as God's becoming human. Or, as Eckhart says: 'God works, and I come into being' (Sermon 65, MW 331ff.). For the meaning of God's becoming human is humanity's becoming out of God and becoming God. By 'becoming' is here expressly not meant spatial progression or the temporal 
cycle of becoming and expiring, but something happening in the now, working across time's chronological course, so to speak in another dimension, but always happening, without cease and at every moment of time. Otherwise, if this activity did not constantly happen, as a product of Creation, but also as a process of becoming human, everything would collapse into the vortex of nothingness. Becoming human and becoming an 'I' are entangled in this process. The offer is all-inclusive, but leaves the personal way open. In Eckhart's own words:

[...] the process, or the engendering and outflowing we are speaking of here, really happens first and above all in the arising instant. This does not happen in movement or in time: it is the goal and end of movement. [...] Therefore it does not logically pass into non-being, or sink into past time. But, if this is so, the process is always in the beginning. But then it is always with us: take away time, and evening becomes morning; and, if it is always as if "in the beginning", then birth is always, arising always: either never or always, because the beginning, or "in the beginning", is always. So it is that the son in the deity, the Word "in the beginning", is always being born, has always been born. ${ }^{15}$

By God's intent, revealed to us in the gradual unfolding of his Creation as revealed by scripture, and by his gracious adoption of humankind, true humanity becomes coordinate with being Christ. Eckhart expresses God's intent in terms of 'witness' and 'giving birth': that is to say, true being strives to break through into this reality of givens, which itself exists only by virtue of the same perennial process. For, in themselves, created beings would be nothing. But the process of God's Creation brings them together in a unity in which they are differentiated only by pure activity (God as sheer works, thus actively giving birth) and pure passivity (being born). Without this process of becoming in a creatural sense, nothing, again, would be revealed. It is only by virtue of this differentiated state, discerned by us in our earthly being, that we as individuals are able to see the way that existence is constituted and to live from that revelation. By this means, and by its sense of self, humanity moves into a higher realm of security in which it is consecrated, not conserved.

This as an art of living is fulfilled in terms of a liberation from impediments, Gelassenheit in Eckhart. There is also the joy of being liberated, enhancing comfort, a joy in partaking in the divine process: 'God works, and I come into being': even that ( $c f$. Sermon 65, MW, $D W$ I, 114,5). My works can become part of God's Wirklichkeit.

What was originally merely on loan now becomes our own. The image of God in humans is disclosed, and united with the primal image. God's becoming human reveals the true possibilities of human nature: being the image as

15 In John n.8, $L W$ III, 8 f. Tr. into English from Dietmar Mieth's modern German $D M B R$, see on this $c f$. Mieth 2014a, 159f. 
a process of birth, as truly being the son. Humanity joins the company of the Trinity, becoming, in Eckhart's German, geborngot (EW II, 288,9).

What I have described here, keeping close to the texts but using modern parlance, has another important point. Human corporeality is always a factor, and even co-penetrates God. For Eckhart does not distinguish the son of God become human and therefore become flesh from any non-corporeal person within the Trinity. Humanity thus stands above the angels, who are diaphanous spirits without individuality, because corporeality enjoys the dignity of Christ's being. As the body individualizes humans, in self-transcendence a remarkable ambivalence arises: while the path of self-transcendence leads away from individuality, and one loses one's individual name (John or Mary), it is only in individuality that the 'best perfection' can be achieved, where the body in the soul is taken into unity with God. This can be understood only if conceived in terms of dynamic relationships, and not combinations of substances. Eckhart thus revolutionizes ontology, ${ }^{16}$ and he is seen today as pioneering a processual structure of relationships, an interpenetration: the one is in the other after the manner of this other; the other is in the one after the manner of this one. In his mature work Buch der Tröstung, Eckhart celebrates this 'two in one' by the erotic image of fevered love (cf. Divine Comfort, MW, 535; DW V, 30, 15ff.).

\section{An example of Meister Eckhart's teaching: self-transcendence on hearing the word of God, as inner resonance without particular preconditions}

I cite Meister Eckhart's sermon on Jesus' encounter with the Samaritan woman at the well ( $c f$. John 4) as an example of the way he treats the need for experience (Erfahrung cf. Sermon 66, MW 58, 300-4; DW II, 108-25) ${ }^{17}$. Here, Eckhart is not confronted with a requirement for a particularly deep level of knowledge on the part of his audience: in the words of the sermon's title - actually the initiating bible passage - they wish to be "good and faithful servants" ( $c f$. Matthew 25:21) of their Lord.

16 Cf. Matsuzawa 2018.

17 Cf. Mieth, Experience 2017 a., 195-197. 
Eckhart wishes, however, to show that, merely because his hearers have no access to a deeper experience of God, they must not think of themselves as Knechte, in the sense of performing only lowly services. Their feeling that they lack the necessary gifts creates the didactic situation: the audience regard themselves as being too 'uncouth and ignorant', and yet, in the sense of the sermon's theme, want to be 'good and faithful servants' of God, and, as such, also accepted or appointed by God. They have no confidence in being especially accepted and esteemed by God. They may therefore be lay brothers of the Dominican Order. Eckhart's didactic intention in telling the story of the Samaritan woman is to demonstrate that nobody is too ignorant to encounter God, in the sense of experiencing a turning point in his or her life. In his own words:

Ich spriche aber mê - erschricket niht, wan disiu vroude diu ist iu nâhe, und si ist in iu ${ }^{18}$ ez enist iuwer keinez sô grop noch sô kleine von verstantnisse noch sô verre, er enmüge diese vröude in im vinden in der wârheit, als si ist, mit vröude und mit verstânne, ê daz ir talanc ûz dirre kirchen komet, jâ, ê daz ich tâlenc gepredige: er mac es waerlîche in im voinden und leben un haben, als daz got got ist und ich mensche bin! Des sît gewis, wan ez ist wâr, und diu wârheit sprichet ez selber. Daz will ich iu bewîsen mit einem glîchnisse, daz stât geschriben in einem êwangeliô.

But I say yet more (do not be afraid, for this joy is close to you and is in you): there is not one of you who is so coarse-grained, so feeble of understanding or so remote but he may find this joy within himself, in truth, as it is, with joy and understanding, before you leave this church today, indeed before I have finished preaching: he can find this as truly within him, live it and possess it, as that God is God and I am a man. Be sure of this for it is true, and Truth herself declares it. I will show you this with a parable which is in the Gospel.

(Sermon 58, $M W$ 301, Pr. 66, DW II)

The peculiarities of this sermon:

It is the sole passage in the German and Latin works of Meister Eckhart where a biblical pericope is translated word for word as a complete text. The text is also a narrative, likewise a rare device in Meister Eckhart. Here, the audience of a sermon is to be immersed in the experience of the Samaritan woman. This too is unique. The aim is the equalization of access to God and a lowering of the threshold in the sense of access without reserve, for all. If Eckhart is here defending the preaching of 'learned' sermons to the unlearned, the point is important for him on the threshold of his trial in Cologne (cf. Divine Comfort, $M W$ 553ff., EW II, 310-13).

Above and beyond this didactic purpose, Eckhart's intention is to dramatize his 'dethroning' of God, which might be summarized by his motto was oben war,

$18 C f$. DW 1, 95.4 ff.: [...] warumbe gât ir uz? War umbe blîbet ir niht in iu selben und grîfet in iuwer eigen guot? Ir traget doch alle wârheit wesenlich in iu. 
ward innen (or: what was remote became near), by raising the level of the water in the well: when the Samaritan woman drops the implements she needs to draw water, her pitcher and rope (mediations), this signifies her realization that the 'true' water is not bubbling in the depths, but as it were in her face at the well's rim. She is, so to speak, eye to eye with Christ. Eckhart frequently says that he does not favor 'seekers after God', but those who allow themselves to be 'found'.

I will here interpolate Jesus' encounter with the Samaritan woman at the well (John 4:6-42), first in Meister Eckhart's ringing translation into Middle High German:

unser herre saz ze einem mâle ûf einem brunnen, wan er was muede. Do kam ein wîp diu was ein Samaritânâ von den heiden, und si brâhte ein kruoc und ein seil und wollte wazzer gewinnen. Und unser herre sprasch ze ir: 'wîp, gib mir ze trinkenne!' Und si antwurte im und sprach: 'war umbe eichest dû von mir trinken? Nû bist dû doch von den juden und ich bin ein Samaritânâ, und unser ê und iuwer ê hânt keine gemeinschaft miteinander.' Dô antwurte unser herre und sprach: 'westest dû, wer von dir trinken eischet, und bekantest die gnâde gotes, vil lîhte iechest dû mir trinken, und gaebe dir von dem lebendigen wazzer. Swer trinket von disem wazzer (hier im Brunnen), den dürstet aber; der aber trinket von dem wazzer, daz ich gibe, den endürstet niemermê, und von im sol entspringen ein brunne des êwigen lebens.' Daz wîp merkte diu wort unsers herren, wan si engienc niht gerne dicke ze dem brunnen. Dô sprach daz wîp: 'herre, gip mir trinken des wazzers, daz mich niht mê endürste.' Dô sprach unser herre: 'ganc und bring her dînen man'. Und si sprach: 'herre, ich enhân keinen man.' Dô sprach unser herre: 'wîp, dû hâst wâr: dû hast aber vünf man gehabet, und den dû nû hâst, der enist niht dîn man.' Dô liez si vallen seil und kruoc und sprach ze unserm herren: 'herre, wer bist dû? Dâ stât geschriben : als messias kumet, den man heizet Kristun, der so uns lêren alliu dinc und so uns diu wârheit kunt tuon.' Dô sprach unser herre: 'wîp, ich bin ez, der mit dir sprichet', und daz wort ervulte allez ir herze. Dô sprach si: 'herre, unser eltern die betten under den böumen ûf dem berge, und iuwer eltern von der jüdischeit die betten in dem tempel: herre, welche von disen betent allerwaerlichst got ane, und welches ist diu stat? Berihte mich des.' Dô sprach unser herre: 'wîp, diu zît sol komen und ist iezuo hie, daz die wâren anbetaere niht aleine suln beten ûf dem berge noch in dem temple, sunder in dem geiste und in der wârheit beten alsô den vater ane; wan got der ist ein geist, und wer in anebeten sol, der sol in anebeten in dem geiste und in der wârheit, und alsolîche anbetaere suochet der vater.' Daz wîp war alsô vol gotes und übervliezende vol und ûzquellende von vülle gotes und wart predigende und rüefende mit lûter stimme und wollte allez daz ze gote bringen und vol gotes machen, daz si mit ougen anesach, als si selber ervüllet was.[...]

Jesus antwürtet, daz ist, daz er sich offenbâret waerlîche und genzlîche und al, als er ist, und ervüllet den mensche alsô übervlüssiglîche, daz er ûzquellende ist und ûzvliezende von übervoller vüllede gotes, als diz wîp tet in einer kurzen zît ob dem brunnen, diu vor gar ungeschicket was dar zuo.

Once our Lord was sitting on a well, for he was weary. Then came a woman who was a Samaritan (one of the heathen), bringing a pitcher and a line, meaning to draw water. And our Lord said to her: 'Woman, give me to drink'. And she answered him, saying: 'Why do you 
ask me for a drink? You are one of the Jews and I am a Samaritan, and those of our faith and your faith have no dealings with each other'. Then our Lord replied, saying: 'If you but knew who it is who asks you for a drink, and if you knew the grace of God, you might perhaps have asked me for a drink, and I would have given you from the living water. Whoever drinks of this water [here in the well] will again become thirsty, but whoever drinks of the water that I give will never thirst again, and from it shall spring up a fountain of eternal life'. The woman was struck by our Lord's words, because she did not like going often to the well. So the woman said: 'Sir, give me some of this water to drink, so that I may never be thirsty again'. Then our Lord said: 'Go and fetch your husband', and she said: 'Sir, I have no husband'. Then our Lord said: 'Woman, you are right: you have had five husbands, but the one you have now is not your husband' ${ }^{19}$ At this she dropped her jug and line and said to our Lord: 'Sir, who are you? It is written that when the Messiah comes whom men call Christ, he will teach us all things and make the truth known to us'. Our Lord said: 'Woman, I am he who is talking to you', and at these words her heart was full. 'Lord', she said, our fathers used to worship under the trees on the mountain, and your fathers the Jews worshipped in the Temple. Sir, which of these worship God most properly, and in which place? Tell me that' Then our Lord said: 'Woman, the time shall come, and is now, when true worshippers shall worship not only on the mountain and in the Temple, but shall worship God in the spirit and in truth: for God is a spirit, and whoever worships him must worship in the spirit and in truth, for such are the worshippers the Father seeks'. At this the woman was filled with God, filled to overflowing, welling over with divine fullness, and she went preaching and crying out with a loud voice, wanting to bring to God everyone she saw, and make them full of God as she was full. [...]

And Jesus will answer, that is, reveal himself truly and wholly and totally, as he is, filling that man to overflowing, so that it comes welling up and running over with the overfull fullness of God, as happened in a short space to this woman at the well, who before was quite unready for it.

(MW 58, 301ff.)

\section{The story in the English Bible, John 4:6-42 (NIV):}

6 Jacob's well was there, and Jesus, tired as he was from the journey, sat down by the well. It was about noon. 7 When a Samaritan woman came to draw water, Jesus said to her, 'Will you give me a drink?' 8 (His disciples had gone into the town to buy food.) 9 The Samaritan woman said to him, 'You are a Jew and I am a Samaritan woman. How can you ask me for a drink?' 10 Jesus answered her, 'If you knew the gift of God and who it is that asks you for a drink, you would have asked him and he would have given you living water.' 11 'Sir,' the woman said, 'you have nothing to draw with and the well is deep. Where can you get this living water? 12 Are you greater than our father Jacob, who gave us the well and drank from it himself, as did also his sons and his livestock?’ 13 Jesus answered, ‘Everyone who drinks

19 Eckhart - concurring with allegorical tradition - likens the five men to the five senses by which it is possible to sin, and he likens 'the husband she does not have' to reason, which can lead to understanding, and shape the will. 
this water will be thirsty again, 14 but whoever drinks the water I give them will never thirst. Indeed, the water I give them will become in them a spring of water welling up to eternal life.' 15 The woman said to him, 'Sir, give me this water so that I won't get thirsty and have to keep coming here to draw water.' 16 He told her, 'Go, call your husband and come back.' 17 'I have no husband,' she replied. Jesus said to her, 'You are right when you say you have no husband. 18 The fact is, you have had five husbands, and the man you now have is not your husband. What you have just said is quite true.' 19 'Sir,' the woman said, 'I can see that you are a prophet. 20 Our ancestors worshiped on this mountain, but you Jews claim that the place where we must worship is in Jerusalem.' 21 'Woman,' Jesus replied, 'believe me, a time is coming when you will worship the Father neither on this mountain nor in Jerusalem. 22 You Samaritans worship what you do not know; we worship what we do know, for salvation is from the Jews. 23 Yet a time is coming and has now come when the true worshipers will worship the Father in the Spirit and in truth, for they are the kind of worshipers the Father seeks. 24 God is spirit, and his worshipers must worship in the Spirit and in truth.' 25 The woman said, 'I know that Messiah' (called Christ) 'is coming. When he comes, he will explain everything to us.' 26 Then Jesus declared, 'I, the one speaking to you - I am he.' 27 Just then his disciples returned and were surprised to find him talking with a woman. But no one asked, 'What do you want?' or 'Why are you talking with her?' 28 Then, leaving her water jar, the woman went back to the town and said to the people, 29 'Come, see a man who told me everything I ever did. Could this be the Messiah?' 30 They came out of the town and made their way toward him. 31 Meanwhile his disciples urged him, 'Rabbi, eat something.' 32 But he said to them, 'I have food to eat that you know nothing about.' 33 Then his disciples said to each other, 'Could someone have brought him food?' 34 'My food,' said Jesus, 'is to do the will of him who sent me and to finish his work. 35 Don't you have a saying, 'It's still four months until harvest'? I tell you, open your eyes and look at the fields! They are ripe for harvest. 36 Even now the one who reaps draws a wage and harvests a crop for eternal life, so that the sower and the reaper may be glad together. 37 Thus the saying 'One sows and another reaps' is true. 38 I sent you to reap what you have not worked for. Others have done the hard work, and you have reaped the benefits of their labor.' 39 Many of the Samaritans from that town believed in him because of the woman's testimony, 'He told me everything I ever did.' 40 So when the Samaritans came to him, they urged him to stay with them, and he stayed two days. 41 And because of his words many more became believers. 42 They said to the woman, 'We no longer believe just because of what you said; now we have heard for ourselves, and we know that this man really is the Savior of the world.'

My line of thought on this text is as follows: What changes does Eckhart make to the text in his translation? (references in italics in the text):

1. He provides the sameritânâ not only with a pitcher, but also with a rope. His purpose at first seems to be to make the text more vivid to his audience: the sense, however, as we shall see, lies deeper. In the course of the narrative, he provides a dramatic heightening, for, when Jesus reveals his special knowledge, Eckhart has the woman drop rope and pitcher with alarm.

2. Second change: the Samaritan woman, not Jesus himself, gives an account of the different religious laws of the Samaritans (Eckhart here calls them 'heathens': a reference to the normal term for Muslims!) and the Jews: praying on Mount 
Gerizim and praying in the Temple at Jerusalem. The problem is thus raised by her for the Messiah to solve, with Eckhart here heightening the tension of the narrative by means of question and answer. We have to keep in mind here that the audience (perhaps in Erfurt) experience in their own lives the tension between Synagogue and Church (the buildings are a stone's throw apart!). It is for this reason that Eckhart does not repeat at this point in his translation the words of Jesus reported here by John, 'Salvation is from the Jews'! That would have compelled him to provide a specific commentary, but he has something else in mind here.

3. A third alteration to the text: instead of 'no longer on the mountain or in the Temple' he says: 'not only on the mountain and in the Temple'. The audience probably understand this in real-life terms as: not only in the synagogue and in the church here, in this place. In this way, Eckhart emphasizes 'worship in the spirit' - which the Father desires, according to Jesus' explicit testimony not as the dissolution of previous places of worship, but as their extension to the individual: everyone can also worship God in his or her heart, as well as in the synagogue and the church; can have God find him or her, just as the Samaritan woman in all her imperfection had herself found by Jesus.

4. Eckhart speaks to his audience in a fourth alteration to the biblical text, seeking, with the immediacy and suddenness of the change in the Samaritan woman, to entice them into an immediate experience: in his version, the Samaritan woman reacts by breaking out in ecstatic jubilation. But Jubil is immediately translated into commitment: the woman becomes proactive, sets off and begins to preach in her village. What she has experienced so changes her that she becomes a messenger of the Messiah. The disciples' amazement at the situation - Jesus is speaking with a heretic, and a woman to boot! - is not shared by Eckhart. He is already clear in his mind: for him, Jews and Christians, men and women, even 'heathens' (Muslims), are actually included 'in the spirit'. Synagogue and Church are there, but what is important is what is going on in the hearts of people: the essential experience, and the consequent changing of lives. ${ }^{20}$

\section{Meister Eckhart}

The hour is coming, and is already here, when true worshippers will worship the Father in the spirit and in the truth; for so does the father wish to be worshiped. God is spirit, and all who worship him must worship in the spirit and in the truth.

20 For Eckhart, the heart is still intellectively informed; it is the centre of corporeal existence, out of which human beings think and understand. 


\begin{abstract}
'Not only on the mountain or in the Temple': so says Eckhart, instead of, as in John's text, 'neither on this mountain nor in Jerusalem'; which would signify today, in the 'spirit' of Eckhart:
\end{abstract}

True worshippers will pray to God the Father or the Mother not only in Jerusalem, not only in Rome, not only in Mecca, but at all places in the gift of the spirit and in the truth that liberates.

The scene at the well, like the story of the Good Samaritan, is frequently portrayed in art. Many cities have their 'Samaritan's Well' (a particularly fine example is to be found in Freiburg in Switzerland). Scenic details are important to the setting in Eckhart's translation: the rope is used because the well is very deep ('Jacob's Well' can still be seen; it is 32 meters deep, a fact that was presumably not unknown in Eckhart's time).

The encounter with the woman is fraught with misunderstandings, as is often the case in John's Gospel. The woman speaks of water at the empirical, physical level; Jesus of 'living water' at a metaphorical level. Similarly, the word 'schöpfen', 'to draw' (water, breath, confidence, hope, courage, etc.) can signify the sensual level. In order to relay water, a vessel is needed. The woman remarks quite soberly that Jesus does not even have a vessel for his water. The human being is the vessel. The human being is the 'place' of God. The life-giving power of God streams through human beings: through every human being. When the human being is the place, 'places' become secondary.

This raises the question: must we fight so over Jerusalem and Mecca, Church and Synagogue, like the Jews and the Samaritans over the mountain of true worship; like, later, the religions of the Christians and the Muslims, who, each in turn, took away the others' places of worship to align them in another direction, the Christians towards Jerusalem, the Muslims towards Mecca; when it was always a matter of only one or two meters' difference in the same easterly direction? Eckhart would have us ask what moves people to pray, what circumstance, and not to what point of the compass and what prominence they direct their prayer.

'Life', as in 'living water', links the two levels of body and soul. The water of the senses is necessary to life; the water of the spirit quickens life.

So the water of life is not the water that drives the mills of intellect ('Paris') and power ('Avignon'). It is the water that comes to human beings themselves in their purified state, streaming into them. It is the moments in which human beings are more intensely alive. That is something different from merely living.

What (according to John and Eckhart) does Jesus mean by 'in the Spirit and in truth'? Human beings themselves, as manifest creatures of God, are the new locations of worship. 'For whom it fits', Eckhart says on this point, for him or her 'it fits everywhere'. A change of location does not bring a change of heart. We 
recognize that change of heart by virtue of actions appropriate to it: 'Why do you venture out? You carry the truth essentially within you' (Sermon $13 \mathrm{MW}$; Pr. 5b, DW 95,6). ${ }^{21}$

We are used to separating places and people, especially by religions. Jesus removes this separation: in reminding us of humans as the central image of God in Creation, and by his own existence as a human, which guarantees the full presence of God.

With the Jesus of John's gospel, Eckhart's text says: ‘[...] the time shall come, and is now [...]'. It is by no means as if humans have to wait for something in order for the text to be realized. Christ comes anyway, through human beings, meaning that he comes not only among people of our own tradition and spiritual home, but also, to our embarrassment, among strangers. 'They were amazed that he was talking with a Turkish woman at the bus stop' would bring the disciples' reaction up to date in today's terms. The image is apt insofar as Eckhart's 'heathen' woman may well represent a Muslim (see above).

A final point of the sermon should not be overlooked: that a Samaritan woman, thus a 'heathen' up to now, is sent as a witness without being required to amend her life. This is conceived similarly to the tale of the sinful woman in Luke 7, who has shown 'great love', for which Jesus (as, later, explicitly Eckhart) is satisfied with the new direction in her life.

\section{Analytical logic and metaphorical speech: understanding Eckhart's thinking}

Eckhart can be understood today only when we consider that, as magister of theology in Paris, he is a metaphysician. His propositions and inquiries (quaestiones) operate at the logical-analytical level of metaphysical conjecture. His expositions of biblical texts, though, envision a doubling of language in terms of an outer 'shell' and an inner 'core'. Eckhart's sermons in Latin and German, which attest to his calling as a member of the Order of Preachers, belong, as he himself asserts, to the same active context as his biblical expositions; that is to say, they use this doubling of language to which metaphor is fitted. To depict by the use of metaphor is at the same time to imply an awareness of the linguistic frontier that it is precisely the task of metaphor to cross. In this context, a word refers to something

$21 C f$. Sermon 2, DW I (8 MW): Möhtet ir gemerken mit mînem herzen, ir verstündet wol, waz ich spriche, wan ez ist wâr und diu wârheit sprichet ez selbe. 
and at the same time refers away from itself. Jesus' phrase in John's gospel where he talks about praying 'in the spirit and in truth', whose exposition by Eckhart I have reproduced here, is given cogency by the fact that it leads beyond the classic 'places' of worship (Jerusalem, Mount Gerizim), without replacing them with any alternative location. The spatial dimension (and the temporal dimension too) is thereby transcended. By 'transcend' is here meant 'to refer beyond itself', or 'to describe something for which there is no specific word for rendering one to one the thing described'.

We cannot, therefore, understand the transcending self in the sense of a spatial change. Transcending in Eckhart's sense leaves space, time, and matter behind. It steps across the normal conventions of the anchoring of the self in place, time, and corporeality, but those conventions remain in place, although sous rature (as Derrida correctly perceived: 'under erasure', Derrida apud Margreiter 1997, 398). Now it is possible to understand this removal from space, time, and corporeality, in which location in space, time, and body nevertheless persists, as transcending into 'another state' (as remarked by Robert Musil in reception of Eckhart), insofar as this other state belongs to the human condition, for example in states of ecstasy, in sexual love, or in hate. This element is familiar to Eckhart. To him, the senses are ecstatic, and are the realm of longing and rage. But his understanding of the flux of transcendence is not primarily anthropological, but theological. That is to say, transcendence is not a product of humanity's search for God; God is the active party: 'pure Wirklichkeit', active always and now. Transcendence, then, is not setting up a ladder 'from below' to God, like the biblical Jacob's ladder often received in religious literature and art to represent the path 'from below upwards'. Eckhart speaks not of a ladder, but of a sudden Durchbruch ('breakthrough'), with humans not acting through their own power, but being drawn by a power whose thrust comes, as it were, into them from above. The human being, aware of this inner flux, and at the same time changing his or her life to fit it, transcends. Self-transcendence is therefore always conceived of from the aspect of its being enabled by God: thus theologically. Nicholas of Cusa discovered Eckhart for himself, received him, and took up these thoughts, while another recipient was Schelling in the 19th century. Ever since, there has been widespread interest in Eckhart's philosophy and theology, and in interfaith spirituality. What is specific to Eckhart is that he makes flux and movement the basis for his metaphorically-grounded verbalization of a process that binds the divine and the human realms. I suggest the image of a vertical ellipse with two foci, but in motion. This may be compared with an old-fashioned paternoster lift that never stands still, and takes you with it when you jump into it from the floor where you are at. Similarly, the human 'breaks through' by taking a leap into movement. 
Eckhart is also able to liken constant flux to the water cycle: water comes from the spring via stream and river to the sea, where it condenses, forms clouds, which soak the ground with rain, so that springs burst forth. ${ }^{22}$ In this conception, there is no substance (perhaps in the sense of Panentheism as deus sive natura), but only relations. Relations define being, the verb defines subject and object. In a flowing movement, different signs exist only in passing. Immediacy reigns overall. There is no third interposed element. Markus Vinzent has recently shown how Eckhart himself eliminates mediators in other spiritual writers (Mechtild von Magdeburg) in favor of immediacy. ${ }^{23}$ Here too belongs the doctrine of 'non-distinctness' between God and humanity, especially in the figure of Christ, but hence also in all who participate in the general process of God's becoming human. In order that this should not be equated with the destruction of difference, Eckhart uses the figure of argumentation distinctio per indistinctionem, or 'distinction by non-distinction'. ${ }^{24}$ Behind this lies the thought that all distinctions need a category external to the thing to be contrasted, a 'third', to come to the aid of the distinction. According to Eckhart, this functions only if God and humans are distinguished as differently being, perhaps locating God as an ens a se beside other beings. This is not possible if, as Eckhart's programmatic assumption has it, being is God (esse est deus). His position is that being cannot be doubled: God is not a stone among other stones. It is therefore not possible to distinguish categories of being. This is presumably what Derrida understood when he distinguished différance from difference. Eckhart attempts to represent immediacy as the 'two in one', thus as difference and unity at the same time, taking fervent loving union as an image, designating it as a metaphor but at the same time referring beyond it.

\section{Self-transcendence on the way into the Modern Period}

Eckhart's spiritual influence during the transition from Late Medieval to Modern Period is marked by something of a hiatus. While the Dominicans Johannes Tauler (1301-1361) - received by Luther - and Heinrich Seuse (1300-1364) linked to him each in his own way, so that it is possible to speak of a 'Dominican Mysticism',

22 The motif of the water cycle may be found, for example, after Book of Wisdom 11:23, in Sermon 94 MW. It is also in Marguerite Porete's The Mirror of Simple Souls (1927) in chapter 82, see cf. Mieth 2017c, 31.

23 Mieth 2019.

24 Cf. Mieth 2014a, 22. 
Eckhart's problems regarding his reception by the Church were not without effect, above all in the Netherlands. Devotio Moderna, which was founded there by Gerrit Groote (1340-1384) as a spiritual counter-movement against Parisian scholasticism, promoting a life of penitence and retreat from the 'world', exerted an influence on Innerlichkeit, not only that of Erasmus of Rotterdam, but in spiritual Protestantism, which evolved into Pietism. ${ }^{25}$ In many places, communities following Devotio Moderna were absorbed into Lutheran communities. Pietistic Innerlichkeit, in the sense of pious withdrawal, and linking with Devotio, leads from Eckhart and Tauler and their reception by Luther. Eckhart, Tauler, and Luther saw the rise of worldly commerce as an encouragement to self-transcendence rather than an impediment. ${ }^{26}$ To Pietists, Innerlichkeit meant withdrawal from worldly superficiality. Like Devotio, it is thoroughly associated with handicrafts in the sense of the ideal link between prayer and labour. Eckhart's Wirklichkeit, as the re-enactment of God's works, and his Innerlichkeit in the midst of commerce, is associated with Pietism insofar as the latter sees Creation in the contemplation of the dynamic, and God at work in human lives. But Pietism lacks Eckhart's immediacy, independent of time and place, which may be termed Durchbruch ('breakthrough'). All of these movements are concerned with finding the correct, pious means for us to realize ourselves as human beings. It was accordingly a long time before Eckhart's vertical immediacy found intellectual consummation again in German Idealism (Hegel, Schelling).

\section{References}

\section{Primary sources}

DW $=$ Meister Eckhart, Die Deutschen Werke, 5 vols., ed. under the auspices of the Deutsche Forschungsgemeinschaft, Stuttgart: Kohlhammer, 1958-.

[vols. I-III and V ed. Josef Quint, vol. IV.1-2 ed. Georg Steer; Das Buch der göttlichen Tröstung (Book of divine comfort) and Reden der Unterweisung (RdU - The Talks of Instruction) in vol. V, 8-105, and Traktat von Abgeschiedenheit (Treatise on Detachment) in vol. V, 400-68]

$E W=$ Meister Eckhart, Werke. Bibliothek des Mittelalters 20 and 21, 2 vols., ed. Niklaus Largier, Frankfurt am Main: Deutsche Klassiker Verlag, 1993.

[vol. I: texts and translations into Modern German by Josef Quint, ed. and commented by Niklaus Largier; vol. I and II: ed. and commented by Niklaus Largier. It contains the Buch

25 Cf. Mieth 2017e.

26 Cf. Mieth 2018. 
der göttlichen Tröstung and the beginning of the Commentary on John, 488-536, with an excellent commentary in German: 835-67]

$L E=$ Lectura Eckhardi, 2 vols., eds. Georg Steer and Loris Sturlese, Stuttgart: Kohlhammer, 2001-2017. $L W=$ Meister Eckhart, Die Lateinischen Werke, Stuttgart: Kohlhammer, 1936-

[Currently curated by Loris Sturlese. The Commentary on John can be found in LW III: Magistri Echardi expositio sancti evangelii secundum Iohannem, eds. Karl Christ et al., 1994]

Meister Eckhart, Einheit mit Gott: Die bedeutendsten Schriften zur Mystik. A selection (since 1979), partly translated into Modern German and commented by Dietmar Mieth, pending new edition, Ostfildern: Patmos, 2014.

\section{English Translation}

MW = The Complete Mystcal Works of Meister Eckhart, revised with a foreword by Bernard McGinn, translated by Maurice O'C Walshe, New York: Crossroad, 2009.

[Abbreviation $M W$ in this text with the English number of the Sermon and with the treatises Talks of Instruction and Divine Comfort.]

\section{Secondary sources}

Beccarisi, Alessandra. 2005. 'Isticheit nach Meister Eckhart. Wege und Irrwege eines philosophischen Terminus', Meister Eckhart in Erfurt, Miscellania Mediaevalia 32. 214-334. de Certeau, Michel. 2010. Die Mystische Fabel, 16. bis 17. Jahrhundert. Berlin: Suhrkamp. Flasch, Kurt. 2010. Meister Eckhart. Philosoph des Christentums. Munich: Beck. Geybels, Hans. 2007. Cognitio dei experimentalis, a theological genealogy of Christian religious experience. Leuven: Peeters.

Hackett, Jeremiah (ed.). 2013. A Companion to Meister Eckhart. Leiden/Boston: Brill. Margreiter, Reinhard. 1997. Erfahrung und Mystik: Grenzen der Symbolisierung. Berlin: Akademie Verlag.

Matsuzawa, Hiroki. 2018. Die Relationsontologie bei Meister Eckhart. Paderborn: Schöningh. Mieth, Dietmar. 1969. Die Einheit von vita activa und vita contemplativa in den deutschen Predigten und Traktaten Meister Eckharts und bei Johannes Tauler: Untersuchungen zur Struktur des christlichen Lebens. Studien zur Geschichte der katholischen Moraltheologie 15. Regensburg: Pustet.

Mieth, Dietmar. 2012. 'Meister Eckhart, Das Buch der göttlichen Tröstung'. In Kanon der Theologie, 3rd edition, ed. Christian Danz, Darmstadt: Wissenschaftliche Buchgesellschaft.103-13. Mieth, Dietmar. 2014a. Meister Eckhart. Munich: Beck.

Mieth, Dietmar. 2014b. 'Gelassenheit', Erbe und Auftrag, Monastische Welt 90. 246-55.

Mieth, Dietmar. 2015. 'Mystik und Metapher. Metaphorische Gottesrede bei Meister Eckhart', Una Sancta 70. 4. 306-16.

Mieth, Dietmar. 2017a. 'Experiential ethics and religious experience with reference to Meister Eckhart'. In Commitments to medieval mysticism within contemporary contexts, eds. Patrick Cooper and Satoshi Kikuchi, Leuven: Peeters. 195-222.

Mieth, Dietmar et al. (eds.). 2017b. Meister Eckhart in Paris and Strasbourg. Eckhart Texts and Studies 4. Leuven: Peeters. 
Mieth, Dietmar. 2017c. 'Geflügelte Motive und Leitbilder: Meister Eckhart und Marguerite Porete'. In Dietmar Mieth et al. (eds.), 23-50.

Mieth, Dietmar (ed.). 2017d. Anfänge der religiösen Selbstbestimmung im Mittelalter= Theologische Quartalschrift Tübingen 197 (2017) 1. Quartalheft, 1-100: Ostfildern: Schwabenverlag.

Mieth, Dietmar. 2017e. 'Innerlichkeit statt Weltgestaltung, Die “Imitatio Christi” des Thomas von Kempen auf dem Weg zu den "Stillen im Lande” (Pietismus)'. In Mystique Rhénane et Devotio Moderna , ed. Marie-Anne Vannier, Paris: Beauchesne. 267-83.

Mieth, Dietmar. 2019. 'Der Aufstieg des Gewerbes: Eckhart, Luther und Max Weber'. In: Jahrbuch der Meister Eckhart Gesellschaft, Bd. 13: Meister Eckhart und Martin Luther, ed. Volker Leppin and Freimut Loeser, Stuttgart 2019.

Mieth, Dietmar (ed.). 2019. Religiöse Selbstbestimmung: Anfänge im Spätmittelalter. MeisterEckhart-Jahrbuch 5. Stuttgart: Kohlhammer.

Mundschenk, Christine (ed.). 1997. Nicolaus von Bibra, der Occultus Erfordensis. Critical edition with introduction, commentary, and German translation. Weimar: Böhlau.

Schöller, Donata. 2009. Enthöhter Gott - vertiefter Mensch. Zur Bedeutung der Demut ausgehend von Meister Eckhart und Jacob Böhme. Munich: Alber.

Vinzent, Markus. 2011. Meister Eckhart, The Art of Detachment. Eckhart Texts and Studies 1. Leuven: Peeters.

Vinzent, Markus. 2014. 'Bildsequenzen der Individualisierungsstufen des Menschen bei Augustinus, Meister Eckhart und Marguerite Porete'. In Religiöse Individualisierung in der Mystik, Eckhart- Tauler-Seuse, Meister Eckhart Jahrbuch 8, eds. Freimur Löser and Dietmar Mieth, Stuttgart: Kohlhammer. 195-220.

Voigt, Jörg. 2012. Beginen im Spätmittelalter, Frauenfrömmigkeit in Thüringen und im Reich. Weimar: Böhlau.

[Especially on sources and their assessment, with copious literature on the Beguine movement in the Middle Ages.]

Witte, Karl-Heinz. 2013. Meister Eckhart. Munich: Alber. 302-30. 
